Portland State University

PDXScholar

\title{
Contrasting Governance Learning Processes of Climate-leading and -lagging Cities: Portland, Oregon, and Phoenix, Arizona, USA
}

Jonathan H. Fink

Portland State University, jon.fink@pdx.edu

Follow this and additional works at: https://pdxscholar.library.pdx.edu/geology_fac

Part of the Geology Commons

Let us know how access to this document benefits you.

Citation Details

Fink, J. H. (2019). Contrasting governance learning processes of climate-leading and-lagging cities: Portland, Oregon, and Phoenix, Arizona, USA. Journal of Environmental Policy \& Planning, 21(1), 16-29.

This Post-Print is brought to you for free and open access. It has been accepted for inclusion in Geology Faculty Publications and Presentations by an authorized administrator of PDXScholar. Please contact us if we can make this document more accessible: pdxscholar@pdx.edu. 


\title{
Journal of Environmental Policy and Planning
}

\section{Contrasting governance learning processes of climate-leading and -lagging cities: Portland, Oregon, and Phoenix, Arizona, USA}

\begin{abstract}
The contrasting histories and political ecologies of two U.S. cities-Portland Oregon and Phoenix Arizona-shed light on their ability to learn from and influence the climate governance of their peers. Portland's populace, political leadership, and business sectors are motivated by environmental and social values, resulting in a collective sense of responsibility for fixing global problems like climate change. The city's pioneering land-use policies, green infrastructure, and multimodal transportation systems solidify its place at the climate action forefront. In contrast, libertarian Phoenix prioritizes real estate, efficient government, tourism, and protection of individual rights - the antithes is of Portland's altruism. However, because Phoenix's economic success depends on reliable supplies of water, power, and clean air, it has become an "accidental" expert in dealing with many of the worst effects of climate change: drought, heat is land, and air pollution. Portland and Phoenix show that cities' reputations as environmental leaders or laggards may not reflect their ability to teach or learn. Rather, opportunities for urban climate governance learning depend on affinities between cities' political-ecological profiles. These examples illustrate how urban les son-learning and policy mobility, originally developed for cases where cities compete, can accelerate around issues like climate change, where cities seek to cooperate.
\end{abstract}

Keywords: climate change; governance learning; urban planning; political ecology

\subsection{Introduction}

In light of national and state governments' growing inability to confront the climate crisis, the need for leadership by cities has become increasingly urgent (Jayne and Ward, 2017; Parnell, 2016; Sassen, 2012). Equally critical is the willingness of cities to learn from each other so that their contributions to climate change mitigation and adaptation can keep pace with rising threats. Changes in governing practice are especially important in enabling the required 
shifts in organization, technology and operations (Bulkeley, 2016). But how does this kind of governance learning take place?

In examining two highly contrasting cities in the American West, this paper explores the mechanisms by which municipal governments and their polities adopt lessons from elsewhere. How does such knowledge transfer take place? How important are networks, a culture of experimentation, and coordination of levels of governance in implementing policies developed by other cities? Do cities prefer to draw on their past experience, or adopt lessons from elsewhere? Who do they consider relevant peers and mentors--their neighbors, with whom they share geographic and political affinities, other similar cities elsewhere, or those global centers with the best reputations as success ful innovators? How objective are these selections, and how much are they influenced by fashion?

Portland, Oregon and Phoenix, Arizona seem about as different as two American cities can be. Compared to the U.S. as a whole, Portland is a politically progressive, socially liberal, ethnically and racially homogeneous, communitarian, transit-friendly, climate-policy leader located in a region with abundant rainfall, cool temperatures, and clean air. Phoenix in contrast is a politically retrograde, socially libertarian, ethnically polarized, individualistic, auto-loving, growth-oriented stronghold of climate change indifference in an extremely arid desert environment critically dependent on water management and prone to severe air pollution. For over 100 years, people have moved to Portland for its rich natural resources, mild climate, and promised quality of life. Phoenix attracts those seeking to escape cold winters and high humidity, make money quickly, and live independently of government influence. Among the values that motivate the political establishment in Portland today are creativity, protection of natural capital, and attention to social causes. In Phoenix, dominant orientations are economic growth for its own sake, efficient management, and the enshrinement of individual rights (Talton, 2015).

These contrasts have a direct effect on how governance has evolved in the two cities, and on their ability to influence global efforts to cope with climate change. Because many residents and governments in Metro Portland define themselves as environmentally and socially aware, they tend toward the cutting edge of participatory climate policymaking. Neighborhood groups, political leaders, and affiliated academics know and readily replicate what their counterparts in other forefront cities are trying. In addition, collaboratively preparing and following plans is the norm 
for Portland's residents and their leaders. This approach helps them solve policy problems that are too complex for an individual organization, increases the transparency of policy-making, and leads to context-appropriate solutions (Sidiki et al, 2015; Chu et al, 2016; Kwon et al, 2014). Portland's governance can thus be characterized as self-reflexive and triple loop (Argyris and Schön, 1978) regarding the way policy-making is carried out, evaluated, and revised.

Conversely, Portland's idealism also contains an anti-scientific streak, with vocal skeptics questioning the benefits of science and technology. As an example, Portland is the largest city in the U.S. that does not fluoridate its water, because of activists' concerns that fluoride is a dangerous chemical additive (Freeze and Lehr, 2009). This tendency has served as a partial brake on Portland's “ecological modernization” (Jänicke, 2007).

Phoenix on the other hand has not generally thought of itself in such environmentally and socially lofty terms. Rather it has sought to be in the economic development vanguard that prioritizes opportunities for business, entrepreneurship and job creation. Planning has been left to government and business, with only a weak mechanism for community input through "village planning committees" (Iwaniec and Wiek, 2014). However, in protecting its long-term financial stability, which at a minimum requires a steady supply of water, power, labor, tourists, and affordable housing, the city has become an "accidental" climate innovator, particularly regarding water supply and air quality. But even though the problems it attempts to solve affect more of the world's population than those that Portland deals with, Phoenix remains below the radar of most scholars of climate change and urban policy because of its overriding conservative reputation. In contrast to Portland, Phoenix's approach to governance and learning is more technocratic (Bäckstrand, 2003), making it potentially more receptive to technical solutions to climate-related problems, as long as they aren't cast in overtly political terms.

The following sections first outline a methodologic framework that examines how the political ecologies, policy mobility, and learning modes of Portland and Phoenix help shape their governance responses to climate change. The article does not seek or claim empirical generalizability, but points at processes and mechanisms that others may uncover els ewhere, albeit not of an exactly similar nature (Payne and Williams, 2005). The paper's counter-intuitive conclusion is that cities' reputations as either climate leaders or laggards do not always correlate with their success in 
communicating the causes and effects of climate change to others, challenging the dominant narrative that leadership necessarily translates to being an effective role model. Instead, cities learn best from others with similar profiles.

\subsection{Approach and Methodology}

The increasing pace of climate change, coupled with the responses shown by a growing number of cities, have led to a recent proliferation of research on urban climate governance processes. The current paper seeks to enhance this literature by contrasting how two polar opposite U.S. cities teach and learn from others. By incorporating the concepts of"lesson drawing" (Rose, 1993), "urban policy mobility" (Baker and Temenos, 2015), and styles of learning (Author 1, 2018), it draws conclusions about the conditions needed to accelerate the exchange of climatehealing information among cities.

Factors that affect how cities learn from each other include the modes used (sequential/parallel, open/controlled), the sources involved (endogenous/exogenous), and the resulting depth achieved (single-, doubleor triple loop) (Author 1, 2018). In addition, meta-learning may occur where such governance knowledge transfer is then taken up at other scales. To unpack these traits in studying our two illustrative cities, we need to identify the different levels of government and non-state players involved in how they are run, and the particular ways in which these levels act and interact.

These assessments of climate governance take place within a framework of urban political ecology, a field taking on more salience as the connections between cities and climate change become clearer, and as more of the world's population becomes urban (Heynin et al, 2006). Originally aimed at critiquing the artificial separation of society from nature, political ecology later incorporated the biologically-inspired metaphors of urban metabolism and circulation to explain how overlapping human and non-human resource flows function and interact in cities (Keil, 2003). These principles have been applied to local issues such as solid waste disposal, water supply, and urban agriculture (Swyngedouw, 2006). But in describing how individual cities relate to the underlying ecosystems on which they depend, urban political ecologists also strive to undo larger-scale damage caused by the original conceptual sin of is olating people from their environment. 
Urban political ecology's ability to help restore environmental balance depends on its moving beyond individual case studies to the rapid transfer of policy innovations from one city to another. The conditions under which this "lesson drawing" (Rose, 1993) and "urban policy mobility" (Baker and Temenos, 2015) work have been carefully delineated in a growing body of research and analysis. These authors have pointed out that lesson-drawing from a city's past or from its peers works best when several conditions are met: the scale of policy intervention to be borrowed should be relatively small, the cause-effect relationship between the policy change and the resultant outcome should be clear, there should be strong interdependence with other existing programs, and, most importantly, there should be a congruity of values between the source city and the learning city. This last condition means that cities like Portland and Phoenix tend to look elsewhere for role models.

Rose's (1993) original formulation of lesson drawing was based on applications, perceived to be zero-sum, in which cities were competing against each other for economic development gains. The same is true for many examples of urban policy mobility (Baker and Temenos, 2015), such as studies of the transfer of Business Improvement Districts from the U.S. to the U.K. (Ward, 2006; Cook, 2008), or considerations of how creativity migrates from one country to another(Cohen, 2015). In contrast, when cities take on climate change, or a host of other environmental issues, the motivation is commonly less competitive; the goal instead is cooperation to achieve a global environmental outcome. Enhancing urban political ecology with the lesson-drawing paradigm offers the promise of powerfully accelerating policy transfer. Some of the enabling factors identified in earlier papers about policy mobility, like transnationalnetworks, or tabulated examples (Broto and Bulkeley, 2013) are particularly relevant here.

The current case study design assumes that insights from an in-depth qualitative analys is of governance learning dynamics in Portland and Phoenix can offer lessons that apply to a wide range of urban realities, both inside and outside the U.S. This 'critical case' approach serves primarily to generate new theory and practical knowledge for its application (Flyvbjerg, 2006; Donmoyer, 2000), but also to validate existing theory (Patton, 2002; Yin, 2009). The patterns and processes observed can thus inform more general interpretations regarding urban climate governance learning and allow implications for research and policy to be derived. 
For data collection, an analys is of pertinent policy documents and press publication s has been performed, as well as semi-structured interviews with 22 key individuals. Prominent among these were Susan Anderson (Director, Portland Bureau of Planning and Sustainability), Grady Gammage Jr (real estate attorney and historian of Phoenix), and Rob Melnick (Arizona State University Professor and Director for 25 years of the leading policy institute in Phoenix). Transcribed interviews were coded according to the above framework for interpretation. In addition, the author has case knowledge based on professional engagement as a university administrator and researcher of urban climate-related policy-making in both cities over more than 20 years.

\subsection{Portland Case Study: The Eme rgence of a "Natural" Climate Leader}

In the 1960s, Portland was one of the most polluted and unins piring cities in the Western US. Natural resource extraction and metals manufacturing, two of the dominant local industrial sectors, contaminated the city's air and its two major rivers, the Columbia and Willamette. Downtown Portland was experiencing the same hollowing out and suburban flight found throughout much of the country, spurred by plans for a web of new freeways and relatively affordable, outlying subdivisions. New commercial construction in the city was utilitarian, efficient, and dull.

Now, fifty years later, Portland is hailed as a model for sustainable transit-oriented development (Hagerman, 2007). Commuting rates by cycling and transit are among the highest in the U.S. (Bloomberg and Pope, 2017). Downtown Portland is a Mecca of walk-able and bike-able neighborhoods, restaurants, and parks, filled with historically-preserved and energy-efficient buildings. Natural storm water infrastructure like bioswales and green roofs has reduced government outlays for pipes and pumps. Tilikum Crossing, the newest span over the Willamette, symbolizes the local ethos by carrying pedestrians, bikes, buses, streetcars and light rail—but no cars or trucks. Although Portland has historically been lacking in racial and ethnic diversity, its policy-makers today try to assure that environmental and social benefits are more equitably distributed.

\subsection{Multilevel and Multisector Coordination of Climate Change Response}


The key factor to understanding Portland's idealistic approach to climate change is the coordinated and consistent nature of federal, state, and municipal government actions over more than 40 years, coupled with reinforcing steps taken by the private sector, regulated utilities, and academia.

In the late 1960s, Oregon Governor Tom McCall and state legislators developed a comprehensive set of planning regulations for the agricultural and urban parts of the state, in order to stop the spread of cities into Oregon's fertile Willamette Valley. These set growth boundaries around all of Oregon's cities, and created Metro, Portland's elected regional government, charged with managing land use inside and outside the region's urban growth boundary (UGB). After more than 40 years, Metro and Portland's UGB remain the only such state-created policy tools in the U.S. (Abbott, 2004).

Portland City government, backed by community activists and non-profits, has also been a policy pioneer. When the Federal Highway Administration sought to slice up the city's neighborhoods with a network of new freeways in the 1970s, the city council and mayor, along with citizen's groups and Oregon's congressionaldelegation, teamed up to protest. Using recently-passed federal legislation, the city shifted highway funds to construct the nation's first modern light rail system. Transit, cycling, and zoning that encouraged small, walkable blocks and coherent neighborhoods, facilitated the density needed to support the UGB.

In the 1990s, Portland residents were among the first in the country to heed warnings from climate scientists about the long-term dangers of global warming. Connections among reduced $\mathrm{CO}_{2}$, non-automotive methods of mobility, energy-efficient construction, and city design fit with the region's prevailing attitudes. The result was the creation and enactment in 1993 of the country's first Climate Action Plan (CAP) (City of Portland, 1993). The project, led by the city's Bureau of Planning and Sustainability (BPS), garnered support from a succession of mayors and city councils. Initially viewed as a largely symbolic gesture, the climate-related policies of Portland and othercities took on greater importance as deniers of climate change blocked federal efforts to reduce emissions (Dunlap and McCright, 2008). The CAP has become one of the Portland region's primary planning instruments, with widespread citizen, corporate, and NGO involvement in the production of its periodic updates (City of Portland and Multnomah County, 2015). 
Federal resources and legislation have supported many of Oregon's and Portland's climate-related policy innovations. Inters tate highway funds paid most of the costs of constructing a downtown expressway loop, which took truck traffic off city streets, making the city more pedestrian-and bike-friendly. More recently, the Oregon congressional delegation helped secure funding for Tilikum Crossing and other additions to Portland's mass transit system. The Obama Administration's implementation of climate-enhancing policies provided federal reinforcement of Portland's leadership.

The construction, architecture, design, and real estate industries, seeing opportunities to profit from Portland's emerging "green" brand, strongly supported the CAP's call for increased energy efficiency of buildings. The city and these partners launched a "We Build Green Cities" campaign (Greater Portland Inc, 2015), marketing Portland's green innovations worldwide. Similarly, a utility- and academic-led movement to promote electric vehicles in the early 2010s evolved into a broad, regional effort to turn Metro Portland into a "smart city" testbed, which has gained recognition from high-tech companies and federal agencies.

\subsection{Scaling and Transferring Portland's Climate Lessons}

Portland's multi-scale, bottom-up approach to climate action (Corfee-Morlot, 2009) has many components. Engaged neighborhood members encourage each other and their city officials to make it easier to walk, bicycle, take transit, and recycle. Local groups emphasizing social priorities assure that equity issues remain part of climate discussions. Multi-city organizations like Metro regional government and TriMet transit authority help synthesize and align the views of the region's many cities.

Portland State University (PSU) is one of many public-sector players that help local governments fulfill their climate mitigation responsibilities and adaptation preparations. For example, the Portland Climate Action Collaborative (Beaudoin and Sherman, 2016) allows Portland's BPS to prioritize Climate Action Plan research questions, which PSU faculty and students then help answer. This approach is now being replicated by philanthropies and city-university consortia, illustrating the benefits of universities accommodating municipal partners' needs, rather than expecting cities to adjust to the peculiarities of academic culture. 
Beyond their metropolitan confines, Portland's officials have long collaborated with their counterparts in cities with similar outlooks, through groups such as ICLEI (Elert, 2016) and the Urban Sustainability Directors' Network. Because of its innovative reputation, Portland was invited into the influential C40 network, despite being below that group's normal population threshold. Planners, politicians, and NGOs from Scandin avia, Asia, and Australia frequent the city to borrow, replicate, and enhance its most progressive ideas, comfortable with the environmentally-sensitive values they encounter.

Portland illustrates how multiple levels of government can reinforce each other's willingness to experiment to achieve goals developed in consultation with grass -roots organizations, universities and the private sector. Progressive policies encourage in-migration by civic-oriented individuals, who in turn elect more like-minded officials and support sympathetic NGOs, which can develop yet more inclusive and participatory approaches to governance, promote crossdomain knowledge transfer, embrace openness and parallel learning processes, and thereby question long -established forms of governing. The formal and informal multi-sector collaboration around climate change mitigation, which integrates input from an unusually large cast of players, is a prime example of this innovation.

On the other hand, creative constituencies moving into Portland's socially- and environmentally-aware milieu, along with idealistic long-time neighborhood activists, have in the past tended toward insularity, focusing on the qualities of place while downplaying the importance of outreach to their counterparts in other cities (including the more conservative communities many of them came from). This inclination reinforces the view that climate mitigation is an elitist concern, limiting the ability of cities like Portland to serve as effective role models. This inward-looking trend has been countered by the long-term tenure of many non-elected city officials, who have found ways to coax mayors and city councils to maintain commitments to reducing carbon emissions and reaching equity goals. This group of experienced bureaucrats has also driven Portland's network participation, resulting in its reputation as a global climate leader.

This apparent contradiction regarding Portland's willingness to influence the climate governance of other cities highlights the contrasting roles of different actors. Municipal workers and their NGO and academic partners lay the foundations for climate leadership that eventually get accepted and promoted by more cautious political and industry 
leaders. Policy mobility and lesson drawing are easier within Metro Portland; the cities learn more readily from their neighbors and from their past experience than they do from cities elsewhere.

\subsection{Phoenix Case Study: The Formation of an Inadvertent Climate Leader}

In the desert city of Phoenix, climate change is the elephant in the room, an existential threat that has only reluctantly been acknowledged. Arizona's libertarian politics are antithetical to the idea that one region would take responsibility for "fixing" such a global problem. Admitting climate risks runs counter to the interests of the "real estate - industrial complex" (Talton, 2015), and is thus downplayed by local governments and business associations. Only recently have modest climate action plans been launched, at the state level in 2006 and in Phoenix in 2009. In contrast to Portland, community input was restricted, reflecting Phoenix's tendency toward top-down governance.

Throughout this period, city officials were accumulating practical expertise about ways to address chronic water shortages, particulate air pollution compounded by desert dust, and the urban heat is land effect, all of which are highly relevant to how other parts of the world adjust to climate change. Thus, instead of zeroing in on its weak articulation of "climate change" governance, we next consider how Phoenix has in fact addressed concerns about water and power supply, motivated by a desire to maintain its growth-based economy.

\subsection{The Role of Multiple Levels of Government in Water Management}

The water management establishment in Phoenix consists of a complex web of public and private sector players (Gammage, 2016). Originally dominated by agricultural interests, the network now also includes real estate developers, city officials, and electric utilities (Talton, 2015). One of its bedrock principles has been that water should be kept cheap, whenever possible subsidized by the Federal Government. The artificially low price of water has discouraged conservation and fits the pro-growth policies that have dominated the city's thinking for more than a half century. 
As in Portland, municipal initiatives in Phoenix have been strongly influenced by state and federal actions. Beginning in 1922, the seven states bordering the Colorado River negotiated a compact for distributing the basin's shared water resource. Only decades later did hydrologists and climatologists determine that the earlier calculations of total availability were inflated by anomalously high flows, meaning that the Colorado River would be unable to meet the region's long-term demands, even without a changing climate (Christensen et al., 2004). When Arizona signed the agreement in 1944, it was allocated more water than its small cities and farm communities needed. However, over the next 30 years, rapid urban growth and expansion of agriculture caused the region's groundwater table to fall alarmingly fast. Phoenix also has had access to water from reservoirs on the Verde and Salt Rivers north and east of the city, originally constructed by the Federal government to produce hydropower and support agriculture. But by the 1960s, it became clear that these existing sources would be insufficient to accommodate anticipated population growth, requiring that the Colorado River be directly tapped.

Between 1973 and 1993, the U.S. Government paid most of the costs for constructing the 541-km Central Arizona Project aqueduct, which brought Colorado River water to Phoenix and Tucson (Grimm and Redman, 2004). However, federal funding came with the stipulation that Arizona require any new real estate development to have an assured 100-year supply of water, codified in the comprehensive Groundwater Management Act of 1980. The act created the Arizona Department of Water Resources, which was mandated to develop plans for quantifying, storing and moving water within four Active Management Areas in basins as sociated with the rapidly urbanizing parts of the state. Since completing the Central Arizona Project, and as a result of federal requirements, Arizona has become a recognized innovator in water management, deriving novel ways to clean, store, mix, and move a combination of municipal and agricultural effluent, ground water, and surface water from the Colorado, Verde, and Salt River watersheds. This experience, which unintentionally also contributed to increased resilience against future climate change impacts, made Arizona a hotbed for new ideas about coping with water shortages, linking it with Israel, Australia, and China.

Because Arizona's state and federal legislators are today dominated by politicians who publicly reject the reality of human-influenced climate change, they resist actions explicitly intended to make the state more resilient to global warming. However, these same leaders readily accept the need for water conservation as a precaution against the periodic droughts that preceded any anthropogenic influences. Similarly, the need for strategies to reduce the urban 
heat is land in Tucson and Phoenix has been justified by a desire to avoid power shortages and utility rate increases, which both could threaten real estate development and tourism, rather than due to fears of increased temperatures due to climate change. While focusing on non-climate explanations for variations in water supply and heat has local political benefits, it has the drawback of limiting the audiences that choose to learn from Phoenix's water management expertise. The city has been sidelined as irrelevant in many climate change discussions where they could potentially have a major impact. For instance, global consortia like the C40 Cities Climate Leadership Group and the Rockefeller Foundation's "100 Resilient Cities" invite the participation of innovative places like Portland, rather than Phoenix, despite the latter's much greater size.

\subsection{The Water-Energy Nexus and the Role of the Utility Sector in Phoenix}

Just behind water as a critical necessity for urban desert dwellers comes air conditioning and the energy required

to generate it. Much of the water that Arizona manages is intimately tied to the generation and consumption of electricity, especially by Phoenix. At the same time, much of the electricity produced in Arizona is used to pump groundwater to the surface and move surface water uphill, either for municipal uses or to cool power plants (Scott et al, 2011). Nearly all climate change models show water becoming scarcer in Arizona; the unwillingness of many politicians to acknowledge this reality threatens the state's long-term viability (Ross, 2011). However, these same individuals will readily discuss power generation, offering a surreptitious way for state policy to incorporate climate projections, and even to reduce carbon emissions.

Nearly 30\% of Arizona's power comes from the Palo Verde nuclear generating facility, the country's largest, located $80 \mathrm{~km}$ west of downtown Phoenix. Palo Verde is the only nuclear plant in the world not built adjacent to a large water body. It annually consumes 20 billion gallons of recycled municipal wastewater, collected from Phoenix and half a dozen neighboring cities (Golden, 2004). Treating and transporting this water also uses large amounts of energy. Most of the rest of Phoenix's electricity comes from coal and natural gas facilities far from the city. One of the coal-fired plants, the Navajo generating station, requires up to 8 billion gallons of Lake Powell water per year for cooling. While these coal- and gas-burning plants are major contributors to Arizona's greenhouse gas emissions, consumers in Phoenix have been much less concerned about their carbon footprints than residents of Portland. 
However, if told that future water scarcity may shut the power plants needed to maintain air conditioning, Phoenicians might be more willing to conserve both water and power.

The obvious missing element in this discussion is renewable energy, given that Arizona has some of the most abundant solar resources in the U.S. The state was relatively slow to develop its solar potential, partly because of the availability of nuclear, coal, and natural gas generation, and partly because legislators and utilities opposed public support for green energy at the expense of utility profits. Arizona's adoption of residential rooftop solar lagged behind cloudier New Jersey and Germany. On the other hand, Arizona has long been a center for solar technology research, led by partnerships between the same utilities, Arizona State University (ASU), the U.S. Department of Energy, and private energy companies (Fink, 2011). The steep drop in the cost of photovoltaic cells, panels, and storage means that unsubsidized solar will soon be fully cost-competitive with carbon-based power in Arizona. Solar energy exported from Arizona could then become a major contributor to reducing U.S. carbon emissions, but only after substantial investments in enhanced interstate transmission.

Ironically, through access to power generated by nuclear, solar, and hydro, Phoenix residents have relatively low per capita carbon emissions, even though that has been much less of a civic priority than in cities like Portland. Carbonfree nuclear power like that at Palo Verde requires major public subsidies for construction, eventualdecommissioning and disposal of the materials that make up the facilities, and site security. Despite their attractiveness from a carbon standpoint, building of new nuclear plants seems unlikely because of political opposition, long-term environmental concerns, and an unwillingness of financial institutions and the federal government to fund risky investments.

Ultimately, reduction in the reliability of Arizona's already-stressed water supplies due to climate change will favor a shift from coal, nuclear, and hydropower to natural gas, solar and wind. In contrast to Portland, where a sense of collective responsibility coupled with municipal government leadership support a transition to renewable energy, mass transit, and denserurban form, in Phoenix, more carbon-responsible policies and practice will likely be forced on the city by climate-related threats to the water and power supplies. 
Because environmental and social awareness and knowledge are more narrowly distributed in Phoenix than in Portland, the public's degree of engagement and interaction with government officials is also considerably less. The dynamic interplay among different levels of government and civic groups, which shapes Portland's climate strategy, is also lacking. It is replaced by highly influential statewide boards that oversee how Phoenix deals with water and power, the most important controls on the city's ability to thrive in the face of climate change.

The elected Central Arizona Project board determines how water is distributed throughout much of the state. Its 15 commissioners influence not only water use, but also energy consumption, real estate development, agriculture, and protection of natural areas. Board members' policy views reflect Arizonans' opinions about a range of contentious is sues including climate change and urbanization (Loomis, 2016). Recent Boards have included technically-proficient members with relatively moderate positions. The Project board serves as the primary public forum in which climaterelated policy matters are assessed, a role that in Portland is played more visibly by the City Council and various neighborhood groups and non-profits.

The Arizona Corporation Commission (ACC), the state's public utility commission, regulates non-municipal utilities. When originally set up, it was made an elected rather than appointed body out of concern that corporations would exert too much control on commissioners directly appointed by a Governor. However, the ACC has recently been made up of Republicans who support the state's largest utility in pushing to reduce the Renewable Portfolio Standard (RPS), arguing that it unfairly subsidizes some consumers' rates (Stockmayer et al., 2011). The RPS determines how much utilities pay consumers for solar energy generated from their rooftops and has a major impact on the state's greenhouse gas emissions. As a reflection of the ACC's political orientation, in the 2016 election, four of the five Republican candidates denied any human influence on climate change.

These two regulatory bodies set much of the climate-related policy in Arizona. The interplay between their roles in controlling water use and power generation takes place largely out of public view, in contrast to the very visible debates that influence climate mitigation in Portland. This lack of transparency, and politicized positions like the ACC's, contribute to Phoenix's reputation as a city characterized by climate change denial. This reputation, in turn, 
is why cities like Portland don't acknowledge Phoenix's expertise in dealing with water and energy shortages, and its potential as a source of lesson learning.

\subsection{Top-Down Policy-Making and Transferability of Climate Governance Lessons from Phoenix}

The political ecology of Phoenix, which attracts individuals seeking independence from government influence, favors top-down environmental policy-making led by government officials and business leaders, rather than the participatory decision-making seen in Portland (Fraser et al., 2006). This tendency has been reinforced in Phoenix by good management. The city was consistently ranked as best-run in the U.S. through the 1990s and 2000s (Denhardt and Denhardt, 2001). As a result, Phoenix enacts policies with less debate, little altered from what is worked out by the City Council and private sector. This simpler pathway makes Phoenix conducive to more rapid, sequential, single loop learning about climate change than what is found in Portland. The rich debates that precede Portland's program formulation reveal new ideas, one reason it is seen as an environmental policy incubator. But Phoenix's municipal government, with its emphasis on efficiency and service to the public, also showcases ways to deliver on climate commitments once the city agrees to them. The Phoenix strategy of outsourcing to professionals, rather than replicating expertise within the government (Kettl, 2000) favors collaboration with outside organizations, in this case with ASU and environmental consulting firms.

\subsection{Discussion: Climate Governance Learning Characte ristics of Portland and Phoenix}

Portland and Phoenix approach climate change in very different ways that reflect their highly contrasting histories and cultures. In this section we look at how the political ecologies of these two cities affect how they are able to learn from and teach other cities about climate change.

Portland's most progressive attributes today trace back to Oregon's decision in the 1970s to create urban growth boundaries around its cities. This and steps that followed gave the region a distinctive pro-environment, populist stamp that attracted individuals and companies who would support similar forward-thinking ideas and positions. This demographic feedback meant that city officials could depend on knowledgeable residents, as well as workers in other 
municipal departments, to take action to support the community values that originally drew them to the region. Thus, new ideas about climate or other environmental topics could be developed by many players acting in concert. This parallel learning mode extended to the export of local ideas: well-connected individuals and organizations used their networks to inform and advise colleagues in other cities about the pros and cons of Portland's programs and policies.

In contrast, early ranchers and farmers attracted to central Arizona's cheap land and sunshine most valued individualism and a lack of government interference. However, growth in Phoenix's harsh desert setting required collective responses like major investments in infrastructure for water and power. The unforgiving heat and lack of water meant Phoenicians had to learn quickly how to cope in order to survive. Residents relied on experts and efficient government to supply basic services and to network with other fast-growing desert cities, rather than participating in governance themselves, freeing them to concentrate on business development. Because of the lack of broad-based public engagement, serial problem-solving has taken place in relatively narrow circles by department workers, consultants, and boards. The main countervailing influence has come from academic partners at ASU, who were experts at working across disciplines. The cumulative result has been sequential and controlled modes of learning carried out largely by municipal government with little external input. Climate change,per se, was a topic that Phoenix city officials long avoided tackling directly, not just because of political aversion, but also because it was seen as a distraction from their core functions.

The main exception to this characterization has been water policy, where Phoenix and Arizona as a whole are widely-recognized innovators. Because reliable water provision is an essential requirement for economic development, it has received a great deal of non-controversial attention. For instance, there is considerable understanding in Phoenix of hydrologic uncertainty, but it is described in terms of periodic persistent drought, not climate change. Since drought is generally considered to be independent of human actions, Arizona's experience with water shortage provides little basis for talking about mitigation strategies. Thus, where activist cities like Portland readily discuss climate change alleviation as well as adaptation, Phoenix mainly addresses the latter.

Nonetheless, Phoenix's extensive knowledge of how to measure and respond to water shortages offers an opportunity for the city to learn in a parallel way about climate change. Different departments within city and state 
government, offices within regulatory organizations, consulting firms and NGOs all contribute to interpretations of how water supplies are being affected by persistently increasing temperatures, changes in land-use, and the frequency and intensity of storms. This part of Phoenix's learning is open in the sense that different bureaus and sectors can be involved; in contrast to Portland, the public rarely participates, either as individuals or as neighborhoods.

These contrasts also extend to how the two cities exchange information with their peers. To implement its Climate Action Plan, Portland takes a broad view, looking at all aspects of city operations that affect carbon emissions. Portland's civic leaders and their partners frequently present at national and international forums, exposing them to the latest global perspectives and providing opportunities for exogenous learning about all aspects of climate change. Historically Portland has been focused more on climate policy than on technology, although recent efforts to compete for federal "smart city" grants have raised awareness of the potential benefits of ubiquitous, distributed sensors. Portland is also emerging as a center of both public and private sector innovation in electric and low-speed autonomous vehicles. This endogenous technological learning, partly within government, not only address es critical local problems but also generates economic development and licensing revenue.

Because Phoenix has fewer staff focusing on climate change, it is less able to learn about policy developments elsewhere. As a result, its knowledge, endogenously gained by overextended workers, is inherently limited. Here again, water is the exception. Private sector and academic environmental engineers, working with city water bureaus, develop new devices and software related to desalinization, soil moisture, hydroponics, and water pumping. Companies and academics from the Middle East and Aus tralia exchange ideas about water-related R\&D with their counterparts in Arizona (e.g., Megdal, 2017), providing opportunities for exogenous learning.

Portland and Phoenix also differ in the depth of their climate change learning, as seen in their use of single-, double-, or triple-loop approaches. As we've discussed, climate change can affect cities in many ways: increased droughts, floods, urban heat island effects, air pollution, sea level rise, aquifer declines, blackouts, disease breakouts, and forest fires. Single-loop responses to these phenomena are simply reactive: purchase more air conditioners when temperatures rise; tell people to stay indoors if air quality declines; lower reservoir levels as storms near. Both cities keep these approaches in their arsenals, although their use does little to avoid or prevent the next crisis. Thanks to the 
focus on efficiency by its well-run bureaucracy, Phoenix handles these activities well and can serve as a role model. Ironically, the idealism of some in Portland might get in the way of deploying pragmatic short-term solutions like expanding air conditioning, because of concerns that these adaptive actions do not adequately address underlying, longer-term problems like climate change.

Double-loop reactions to climate change involve "adjusting the rules" that caused the problems. In Phoenix, these could include planting more trees and installing shade structures to reduce the intensity of heat island episodes; using permeable pavement in parking lots to reduce runoff and restore depleted urban aquifers; and paying residents to convert their lawns into desert landscaping. These steps, pioneered by other desert cities, have only recently come to Phoenix and its neighbors. The costliest response to the threat of drought has been the increasing dependence on Central Arizona Project water.

Portland's double-loop actions include extensive use of bioswales, planted roofs, and other green infrastructure to reduce runoff and restore aquifers; subsidization of the installation of residential insulation and solar panels to increase resilience to power shortages; and identification of more emergency shelters for homeless populations to use during increasingly common heat waves. As with all aspects of Port land's policy development, these activities include considerable public input.

It is in the realm of triple-loop learning about climate change where Phoenix and Portland differ most dramatically. Described in shorthand as "learning about learning," this mode involves reflection about the underlying conditions that cause a problem, and consideration of whether or not the right problem is being addressed. For the present case, a city's triple-loop response could involve altering the behaviors that cause the climate to change in the first place. These actions can be individual or institutional. Because Phoenix does not consider climate change mitigation to be its responsibility, nearly all of its focus is on adaptation, with its learning limited to single- and doubleloop types. In contrast, Portland was the first city with a climate action plan, which by definition is a triple-loop activity, in that it seeks to fix an underlying problem outside the jurisdiction of its residents. 
As its propensity for triple-loop learning demonstrates, one of the signature characteristics of Portland's governance is a non-hierarchical distribution of expertise. Thus, many new ideas come neither from the public nor their leaders, but rather from mid-level government technocrats with uncommonly long tenure in municipal agencies and strong networks with colleagues in othercities and in universities. For the case of climate change, this can lead to parallel learning processes, as different bureaus (Planning and Sustainability, Housing, Transportation, Environmental Services) simultaneously try new approaches within their immediate purviews that all advance community goals laid out in documents like the Climate Action Plan. Similarly, this flat structure alters the role of academic collaborators; they can more equally co-produce new knowledge about climate change mitigation with their city partners than wo uld be the case if the information exchange were more narrow or unidirectional. In Portland, interdisciplinarity, an obligatory hallmark of the academic study of cities, comes as much from the partnerships cultivated by scholars as from the university researchers themselves. Finally, the professionallongevity of many of Portland's managers leads to more endogenous, sequential learning, because these individuals remember past successes and problems and can adjust their actions accordingly.

While for many cities the arrival of climate change offered a completely new set of challenges, for Phoenix, they were already quite familiar. The mechanisms earlier put in place to make the city livable (and to support its real estate interests) were similar to those required for dealing with a world that was suddenly seen to be heating up and drying out. Therefore, from a technical standpoint, Phoenix has many lessons to offer other cities about climate resilience, long-term planning, water and energy conservation, and the migration of refugees, all in the context of climate change. Its pragmatic, pro-business, individualistic orientation contrasts with the more collectivist attitudes that characterize Portland, making it relatively straightforward to come to a political consensus. However, these attractive attributes have been sullied by the emergence of a radically conservative political agenda at state and local levels, which rejects the idea of an anthropogenic cause for climate change. This movement, which predates the similar national trend, makes many other cities reluctant to look to Phoenix as a climate change role model, hindering lesson drawing and policy mobility that might otherwise take place.

\subsection{Conclusions}


A comparis on of Portland and Phoenix illustrates some of the opportunities and challenges cities face in achieving the knowledge transfer necessary to address climate change. In Portland, governance learning involves a combination of parallel and experimental modes that draw on both endogenous and exogenous sources. Endogenous influences include a range of local climate stakeholders; exogenous inputs come from other policy fields and other juris dictions through extensive networks and interdisciplinary, multisector collaborations. Climate-related governance in Portland evolves through a combination of double- and triple-loop learning activities, which change the institutions as well as their practices. The most prominent triple-loop example is the city's Climate Action Plan, through which it implicitly and explicitly takes responsibility for societal problems well beyond its jurisdiction.

In Phoenix, governance learning about climate is based on sequential and controlled modes, which draw on endogenous assessments from a limited pool of local experts and outside contacts, resulting in mostly single-loop learning that addresses specific local problems like heat island mitigation. The main exception is in water policy, where Phoenix has, of necessity, developed deep proficiency and a global network of peers. In this one climaterelevant domain, Phoenix has double-loop learning with parallel input from multiple city, county, and state departments, as well as regulatory agencies.

In both cities, local universities play a critical role in knowledge provision and leadership. PSU is one of many public-sector partners that help Portland fulfill its climate mitigation responsibilities and adaptation preparations, contributing to the city's pervasive parallel learning approach. In contrast, ASU today is the most significant formulator of economic development and environmental policy in Phoenix. As the city's dominant intermediary, ASU provides both theoretical and practical knowledge about climate change, as well as access to external networks. Phoenix thus has sequential learning from a single external source (ASU), rather than from its own staff. Here again, water is the exception. In addition to university input about water quality and supply, Phoenix can draw on more than a century of experience coping with the uncertainty of water availability. Parallel learning across city, county, and state departments, coupled with private sector and federal agency input, give Phoenix a solid foundation on which to deal with the water implications of such climate change-related risks as flooding, urban heat, and power disruptions. 
Oregon's natural abundance and mild setting mean that the climate-related problems Portland confronts, like increased heat island and risk of seasonal drought, flooding, or fires, are less pressing than those dealt with in physically harsher places. In addition, because of less local urgency, climate mitigation and adaptation tend to have a lower priority than issues like housing affordability and seismic preparedness. Hence, for cities facing immediate threats of drought, air pollution, or sea-level rise, Portland is a less obvious role model. Finally, Portland's status among climate mitigation elites may intimidate less advanced cities.

If cities are going to borrow ideas from elsewhere, they should come from places or networks that local stakeholders know and respect as familiar peers or peer-aspirants. Thus, cities like Portland will most readily try approaches developed in places at similar stages of environmental, social, and economic awareness, like its fellow Cascadian cities of Seattle and Vancouver. The benefits of this kind of policy mobility have been widely referenced but achieving them in practice is challenging due to limited municipal staff time and expertise. City officials are responsible for making their jurisdictions function well, not for "saving the world." Until new mechanisms can funnel resources to cities for fulfilling this altruistic role, their efforts will not be economically sustainable. Philanthropies have begun to facilitate this transformation, but ultimately, national governments are the only players with sufficient resources to let cities realize their potential as climate change champions.

In some ways, these two cities provide windows into the past and the future of urban-based climate change mitigation and adaptation, and thus different scenarios for policy mobility. With an abundance of reasonably-priced water and carbon-free power, Portland's residents have to work harder to translate their governance lessons into forms that can also help others outside of their benign bubble. As the global climate crisis gets more extreme, fewer and fewer cities will have the policy leeway that has blessed Portland. Instead, they will have to choose the least bad among unappealing options. Because of its geographic setting and realpolitik, Phoenix is better prepared to immediately advise the growing numbers of climate change victims, if it decides this is a priority, and if it can get their attention. Portland and Phoenix illustrate how cities' reputations, either as global leaders or as experts in particular domains, do not necessarily make them effective sources of climate-related policy mobility. Governance learning between cities works best when they can recognize or imagine themselves as having kindred interests. 


\subsection{Acknowledgements}

The author thanks all of the interviewees for their insights and assistance.

\subsection{References}

Abbott, C. (2004) Centers and Edges: Reshaping Downtown Portland. In Ozawa, C. P. (ed.), The Portland Edge: Challenges and Successes in Growing Communities. Washington D.C.: Island Press, pp. 164-183.

Argyris, C. and Schön, D.A. (1978) Organizational Learning, Reading MA: Addison-Wesley, 356 pp.

Author 1 (2018) Guest Editorial: Learning and meta-learning in urban climate governance:Concepts, key issues and challenges ahead. Journal of Environmental Policy \& Planning, under review.

Bäckstrand, K. (2003) Civic science for sustainability: reframing the role of experts, policy-makers and citizens in environmental governance. Global Environ Polit 3(4):24-41.

Baker, T. and Temenos, C. (2015) Urban policy mobilities research: Introduction to a debate. International Journal of Urban and Regional Research 39, 824-827.

Beaudoin, F.D. and Sherman, J.D.B. (2016) Higher education as a driver for urban sustainability outcomes: The role of Portland State University Institute for Sustainable Solutions. In Wortham-Galvin, B.D., Allen, J.H., and Sherman, J.D.B. Let Knowledge Serve the City. New York: Routledge, 200 pp.

Bloomberg, M.R. and Pope, C. (2017) Climate of Hope: How cities, businesses, and companies can save the planet. New York: St. Martin's Press, 272 pp.

Broto, V.C. and Bulkeley, H. (2013) A survey of urban climate change experiments in 100 cities, Global Environmental Change 23(1),92-102.

Bulkeley, H. (2016) Accomplishing climate governance. New York: Cambridge University Press, 204 pp.

Christensen, N.S., Wood, A.W., Voisin, N. (2004) The effects of climate change on the hydrology and water resources of the Colorado River Basin. Climatic Change 62, 337-363.

Chu, E., Anguelovski, I., and Carmin, J.A. (2016) Inclusive approaches to urban climate adaptation planning and implementation in the Global South. Climate Policy 16, 372-392.

City of Portland (1993) Global Warming Reduction Strategy. City of Portland, Nov. 1993. https://www.portlandoregon.gov/bps/article/112110. Accessed May 2, 2017. 
City of Portland and Multnomah County (2015) Climate Action Plan: Local strategies to address climate change. https://www.portlandoregon.gov/bps/article/531984. Accessed June 3, 2017.

Cohen, D. (2015) Grounding mobile policies: ad hoc networks and the creative city in Bandung, Indonesia. The Singapore Journal of Tropical Geography 36.1, 23-37.

Cook, I.R. (2008) Mobilising urban policies: The policy transfer of US business improvement districts to England and Wales. Urban Studies 45, 773-795.

Corfee-Morlot, J., Kamal-Chaoui, L., Donovan, M.G., Cochran, I., Robert, A. and Teasdale, P.J. (2009) Cities, climate change and multilevel governance. OECD Environmental Working Papers 14.

Denhardt, J. V. and Denhardt, R. B. (2001) Creating a Culture of Innovation: 10 Lessons from America's Best Run City. Arlington, VA: PricewaterhouseCoopers Endowment for the Business of Government, 107-141.

Donmoyer, R. (2000) Generalizability and the single case study, In: Gomm, R., Hammersley, M., Foster, P. (Eds.), Case Study Method: Key Issues, Key Texts. Sage, London, pp. 45-68.

Dunlap, R. E. and McCright, A. M. (2008) A widening gap: Republican and Democratic views on climate change. Environment 50 (5), 26-35.

Elert, L. (2016) The double edge of cutting edge: Explaining adoption and no nadoption of the STAR rating system and insights for sustainability indicators. Ecological Indicators 67, 556-564.

Fink, J.H. (2011) Phoenix, the role of the university, and the politics of green-tech, in Slavin, M.I., editor, Sustainability in America's cities: Creating the green metropolis, Washington DC: Island Press, 69-90.

Flyvbjerg, B. (2006) Five Misunderstandings About Case-Study Research. Qual. Inq. 12, 219-245.

Fraser, E.D.G., Dougill, A.J., Mabee, W., Reed, M.S., McAlpine, P. (2006) Bottom up and top down: Analysis of participatory processes for sustainability indicator identification as a pathway to community empowerment and sustainable environmental management. Journal of Environmental Management 78, 114-127.

Freeze, A.R. and Lehr, J. (2009) The Fluoride Wars: How a modest public health measure became America's longest running political melodrama. London: Wiley, 400 pp.

Gammage, G., Jr. (2016) The Future of the Suburban City: Lessons from Sustaining Phoenix. Washington, D.C.: Island Press. 208 pp.

Golden, J.S. (2004) The built environment induced urban heat island effect in rapidly urbanizing arid regions — a sustainable urban engineering complexity. Environmental Science 1, 321-349. 
Greater Portland Inc (2015) Greater Portland Global: Global trade and investment plan http://www.greaterportlandinc.com/assets/documents/Resources/GPG\%202015.pdf Accessed June 3, 2017.

Grimm, N.B. and Redman, C.L. (2004) Approaches to the study of urban ecosystems: The case of Central Arizona-Phoenix. Urban Ecosystems 7(3), 199-213.

Hagerman, C. (2007) Shaping neighbourhoods and nature: Urban political ecologies of urban waterfront transformations in Portland, Oregon, Cities 24 (4), 285-297.

Heynen, N., Kaika, M. and Swyngedouw, E., editors (2006) In the Nature of Cities: Urban Political Ecologyand the Politics of Urban Metabolism. London: Routledge, $271 \mathrm{pp}$.

Iwaniec, D. and Wiek, A. (2014) Advancing sustainability visioning practice in planning — The general plan update in Phoenix, Arizona. Planning Practice and Research 29 (5), 543-568.

Jänicke, M. (2007) Ecological modernization: New perspectives.Journal of Cleaner Production 16 (5), 557-565.

Jayne, M. and Ward, K., editors (2017) Urban theory: New critical perspectives. London: Routledge.

Keil, R. (2003) Urban political ecology. Urban Geography 24, 723-738.

Kettl, D. F. (2000) The transformation of governance: Globalization, devolution, and the role of government. Public Administration Review 60, 488-497.

Kwon, M., Jang, H.S. and Feiock, R.C. (2014) Climate protection and energy sustainability policy in California cities: What have we learned? Journal of Urban Affairs 36, 905-924.

Loomis, B. (2016) Central Arizona Project election will determine who guides agency through water-scarce times. Arizona Republic. http://www.azcentral.com/story/news/politics/elections/2016/10/28/central-arizona-projectelection-determine-who-guides-agency-through-water-scarce-times/92729936/. Accessed June 11, 2017.

Megdal, S. (2017) My Turn: Israel's water lesson for Arizona. Arizona Republic. http://www.azcentral.com/story/opinion/op-ed/2015/11/01/israel-water-desalination/74844270/. Accessed August 30, 2017.

Parnell, S. (2016) Defining a global urban development agenda. World Development 78, 529-540.

Patton, M.Q. (2002) Qualitative research and evaluation methods, 3rd. ed. Thousand Oaks, CA: Sage Publications, $832 \mathrm{pp}$.

Payne, G. and Williams, M. (2005) Generalization in qualitative research. Sociology 39, 295-314. 
Rose, R. (1993) Lesson-drawing in public policy: A guide to learning across time and space. Chatham, NJ.: Chatham House Publishers, 192 pp.

Ross, A. (2011) Bird on Fire: Lessons from the world's least sustainable city. Oxford: Oxford University Press, 297 pp.

Sassen, S. (2012) Cities in a World Economy - Fourth Edition. Thousand Oaks, CA: Sage Publications, 200 pp.

Scott, C.A., Pierce, S.A., Pasqualetti, M.J., Jones, A.L., Montz, B.E., and Hoover, J.H. (2011) Policy and institutional dimensions of the water-energy nexus. Energy Policy 39, 6622-6630.

Sidiki, S.N., Carboni, J., Koski, C. and Sadiq, A.A. (2015) How policy rules shape the structure and performance of collaborative governance arrangements. Public Administration Review 74, 536-547.

Stockmayer, G., Finch, V., Komor, P. and Mignogna, R. (2011) Limiting the costs of renewable portfolio standards: A review and critique of current methods. Energy Policy 42, 155-163.

Swyngedouw, E. (2006) Metabolic urbanization: The making of cyborg cities, in Heynen, N., Kaika, M. and Swyngedouw, E., editors, In the Nature of Cities: Urban Political Ecology and the Politics of Urban Metabolism. London: Routledge, 21-40.

Talton, J. (2015) A Brief History of Phoenix. Stroud, UK: The History Press, 144 pp.

Ward, K. (2006) 'Policies in Motion', Urban management and state restructuring: The trans -local expansion of business improvement districts. International Journal of Urban and Regional Research 30, 54-75.

Yin, R.K. (2009) Case study research: Design and methods. Thousand Oaks, CA: Sage Publications. 312 pp. 